Original Article

\title{
Antioxidant and antimicrobial activities of Thymus vulgaris essential oil contained and synthesis thymus (Vulgaris) silver nanoparticles
}

\author{
Atividades antioxidante e antimicrobiana do óleo essencial de Thymus vulgaris \\ contido e síntese de nanopartículas de prata de timo (Vulgaris)
}

\author{
S. K. Aldosary ${ }^{a}$ (D) S. N. A. El-Rahman ${ }^{\text {b* }}$ (D) S. S. Al-Jameelc (iD and N. M. Alromihid \\ aDepartment of Biology, College of Science, Imam Abdulrahman Bin Faisal University, Dammam, Saudi Arabia \\ ${ }^{\mathrm{b} C r o p s}$ Technology Research Department, Food Technology Research Institute, Agricultural Research Center, Giza, Egypt \\ 'Department of Chemistry, College of Science, Imam Abdulrahman Bin Faisal University, Dammam, Saudi Arabia \\ ${ }^{\mathrm{d}}$ Microbiology Lab, King Fahad University Hospital, Khobar, Saudi Arabia
}

\begin{abstract}
Several species of thymus have therapeutic properties, so they are used in traditional medicine. In this work was carried out to synthesize Thymus vulgalis silver nanoparticles $\left(\mathrm{TSNP}_{\mathrm{S}}\right.$ ) and evaluate antioxidant and antimicrobial activities of TSNP $\mathrm{S}_{\mathrm{S}}$ and $T$. vulgalis essential oil extract (TEOE). The essential oils analyzed by GC-MS and were characterized. Major compounds of phenol, 2 methyl 5 (1 methylethyle)(CAS), thymol and 1,2 Benzene dicarboxylic acid, 3 nitro (CAS) $\left(48.75 \%, 32.42 \%\right.$ and $8.12 \%$, respectively) were detected. Results demonstrated that the TSNP $_{S}$ gave a highest DPPH radical scavenging activity, it was obtained 97.2 at $1000 \mathrm{ug} / \mathrm{ml}$. TSNP , Thymus + Hexane $(\mathrm{T}+\mathrm{H})$, Thymus + Ethanol $(\mathrm{T}+\mathrm{E})$ gave the greatest antimicrobial activity than amoxicillin $(\mathrm{AM})$ and ciprofloxacin (CIP). In conclusion: The essential oil of thymus (Vulgaris) and thymus (Vulgaris) silver nanoparticles can be a good source of natural preservatives as an antioxidant and antimicrobial agents for increasing the shelf life of foodstuffs. Keywords: antioxidant, antimicrobial, thymus (Vulgaris), GC/MS, essential oil, silver nanoparticles.

Resumo

Diversas espécies de timo possuem propriedades terapêuticas, por isso são utilizadas na medicina tradicional. Neste trabalho foi realizado para sintetizar nanopartículas de prata Thymus vulgalis (TSNPS) e avaliar as atividades antioxidante e antimicrobiana de TSNPS e extrato de óleo essencial de T. vulgalis (TEOE). Os óleos essenciais analisados por GC-MS e foram caracterizados. Os principais compostos de fenol, 2 metil 5 (1 metiletilo) (CAS), timol e ácido 1,2 Benzenodicarboxílico, 3 nitro (CAS) (48,75\%, 32,42\% e 8,12\%, respectivamente) foram detectados. Os resultados demonstraram que o TSNPS deu uma maior atividade de eliminação do radical DPPH , foi obtido 97,2 a $1000 \mathrm{ug} / \mathrm{ml}$. TSNPS, Timo + Hexano (T + H), Timo + Etanol (T + E) deu a maior atividade antimicrobiana do que amoxicilina (AM) e ciprofloxacina (CIP). Em conclusão: O óleo essencial de nanopartículas de prata do timo (Vulgaris) e do timo (Vulgaris) pode ser uma boa fonte de conservantes naturais como agentes antioxidantes e antimicrobianos para aumentar a vida útil de alimentos.
\end{abstract}

Palavras-chave: antioxidante, antimicrobiano, timo (Vulgaris), GC/MS, óleo essencial, nanopartículas de prata.

\section{Introduction}

There are 350 species world wide of the genus Thymus (Figure 1) which belongs to Lamiaceae (Labiatae) family. It is known for its large morphological and chemical variety. In addition, it has a various distinguished composition used widely in herbal medic ne products. The essential oils of different species of the Thymus genus have been lately inspected for their traditional uses and heavily investigated as potential source of anti-inflammatory, antibacterial, antioxidant, antifungal, sedative, anti aflatoxinogenic and antiviral-(Miura and Nakatani, 1989); (Katsiotis, et al., 2009).
The advancement of Nanotechnology has open new horizons in the life sciences especially in biotechnology and biomedical devices (Slman, 2012). It made it possible for nanoparticles to exhibit improved or even new properties based on particular characteristics such as distribution, size and morphology. Due to its simplicity and environmental friendliness, plant-mediated biological synthesis is gaining popularity in recent years. Plant extracts for nanoparticles synthesis can be very useful in biological process as it avoids the detailed process of maintaining cell cultures and can

*e-mail: soheirkenawy@yahoo.com

Received: October 17, 2020 - Accepted: February 24, 2021

This is an Open Access article distributed under the terms of the Creative Commons Attribution License, which permits unrestricted use, distribution, and reproduction in any medium, provided the original work is properly cited. 


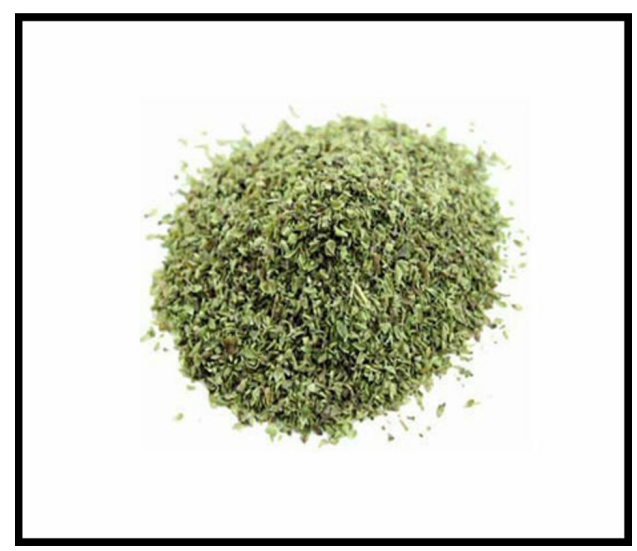

Figure 1. Thymus sp.

be used for large-scale nanoparticles synthesis. For long time, silver has been known for its inhibitory effect toward several bacterial strains and micro-organisms usually exist in medical and industrial process (Krutyakov et al., 2008). Moreover, it has been studied with several pathogens such as cancer cells, arthropods vectors infections, cosmetics, medicine and food. Green chemistry suggests using plant for silver nanoparticles synthesis to avoid producing toxic byproduct. Plant mediated nanoparticles synthesis is a preferred method over other synthesis methods as it is friendly to the environment, cost effective and safer for human therapeutic use (Kumar and Yadav, 2009).

Antioxidants are very important as they prevent oxidative stress which could lead to many deteriorating diseases. Plants are considered the main source of antioxidants and the preservative effect of their spices and herbs indicates that there are anti-oxidative and antimicrobial components in their tissues (Javanmardi et al., 2003). The health-benefits of antioxidants from plants is believed to stem primarily from their protective effects by addressing reactive oxygen species that are believed to play an important role in various pathogens, premature aging, chronic diseases and oxidative degradation of cosmetics, foods, and pharmaceuticals (Kaur and Kapoor, 2001). Traditionally the thymus capitatus is considered an antioxidant. It has a key role in preventing several pathological diseases, such as cardiovascular, cancer, and neurodegenerative diseases, and is believed to be linked with oxidative stress (Losso et al., 2007). The synthetic antioxidants used in food industry are highly unstable and volatile which made their safety and effectiveness being often questioned (Sokmen et al., 2004). It is suspected that synthetic antioxidants such as butylated hydroxy anisole (BHA), tertiary butylhydroquinone (TBHQ), butylated hydroxytoluene (BHT), and propyl gallate (PG) cause or enhance the harmful health effect, therefore, interest has been intensified in finding naturally occurring antioxidants which have the potential to protect humans from damage caused by oxidative stress (Scalbert et al., 2005).

Due to the increased demand on natural product by consumers and their willingness to pay for relatively expensive natural foods (Sebranek and Bacus, 2007), therefore, the present study was carried out with the aim of: 1-Determination of chemical composition of the essential oil of thymus (Vulgaris) extracted by GC/MS. 2-Characterization of synthesized prepared silver nanoparticles. 3-Determination of antioxidant and antimicrobial activities of thymus (Vulgaris) essential oil and thymus (Vulgaris) silver nanoparticles.

\section{Materials and Methods}

Thyme (Vulgaris) leaves used in this work were collected from local markets, Dammam, Saudi Arabia. The leaves were washed by water and drying in the air for 5 days, then were kept in the hot air oven at $60^{\circ} \mathrm{c}$ for $24 \mathrm{hrs}$. After that, they were ground to a fine powder.

\subsection{Extraction of the essential oil extract}

The oil was extracted by soaking in n-hexane at room temperature for 72 hours. The extract was filtered after 24 hours/3 days and evaporated to dryness.

\subsection{Gas Chromatography-Mass Spectrometry (GC-MS) analysis}

The instrument of GC/MSD Polaris Q (Thermo Finnigan, USA) was used to perform the analysis of GC-MS spectrometry. Briefly, capillary column (HP5MS) (thickness of film, $0.32 \mathrm{~mm} ; 30 \mathrm{~m} \times 0.25 \mathrm{~mm}$ i.d ) with program of temperature $\left(40^{\circ} \mathrm{C}\right.$ initial oven temperature for $5 \mathrm{~min}$; gradient of $4^{\circ} \mathrm{C}$ min- 1 ramped to $200^{\circ} \mathrm{C}$ and held for $5 \mathrm{~min}$; gradient of $20^{\circ} \mathrm{C}$ min- 1 ramped to $280^{\circ} \mathrm{C}$ and held for $10 \mathrm{~min}$ were used. The temperature of injector-line was $260^{\circ} \mathrm{C}, 10: 1$ split ratio was applied. The flow rate of carrier gas (Helium) was $1.0 \mathrm{~mL}$ min-1. The temperature of interface was $280^{\circ} \mathrm{C}$. The electron ionization system (70eV) was used as GC-MS detection. 30-350 amu mass range was used to record Totalion current chromatograms. The components were identified by comparing authentic standards retention times with their relative retention times, and mass spectra with NIST, WILEY GC-MS system library data and literature data (Mathe et al., 2004).

\subsection{Silver nanoparticles synthesis}

Silver nitrate $(1 \mathrm{mM})$ was added to the extracts of plant separately to get $200 \mathrm{ml}$ of final solution, then centrifuged for $25 \mathrm{~min}$ at $18,000 \mathrm{rpm}$. 50 to $95^{\circ} \mathrm{C}$ was used to heat the supernatants. Within $10-15$ minutes during heating process the change in the color of the solution was observed. This changes in the color indicate that silver nanoparticles (SNPs) formation (Savithramma et al., 2011).

\subsection{Transmission Electron Microscopy (TEM)}

Transmission electron microscope was used to study the surface morphology and size of the nanoparticles by. (FEI, TEM, Czech Republic working accelerating voltage was $80 \mathrm{Kv})$.

\subsection{The activity of DPPH radical scavenging}

The activity of Radical scavenging was determined by the method of Moreno et al. (2000), they used 2, 
20-diphenylpicrylhydrazyl (DPPH) as a free radical with some modifications. The stable radical DPPH was used as a reagent in this spectroscopic assay. Briefly, the methanol was used to dissolve each sample $(200 \mathrm{~mL})$ of various concentrations and added to the DPPH solution $(50 \mathrm{~mL})$ $(0.15 \mathrm{mM}$ in methanol) in microtitre plate (96-well). $517 \mathrm{~nm}$ was used to measure the absorbance decrease of solution after incubated in the dark for 30-min at room temperature. The blank was methanol and control was $\mathrm{DPPH}$, without essential oil. The synthetic references were ascorbic acid, BHA and BHT. Then, the DPPH radical reduction was calculated. For the final results, $\mathrm{RC}_{50}$ values (the concentrations required for a $50 \%$ reduction of DPPH $(0.15 \mathrm{mM}))$ were calculated from the absorbance diminished by $50 \%$. The experiment was performed in triplicate.

\subsection{Bacterial strains}

Standard strains were used, E.coli ATCC 25922, Klebsiella pneumoniae ATCC 100324, Kelbsiella oxytoca ATCC 700324, Pesudomones aeruginosg ATCC 27853, Acinetobacter baumanii ATCC mra 747, Enterobacter aerogenes ATCC 13048, Streptococcus dgalacticae ATCC 12336, Staphylococcus epidermindis ATCC 12228, Streptococcus pyogenes ATCC
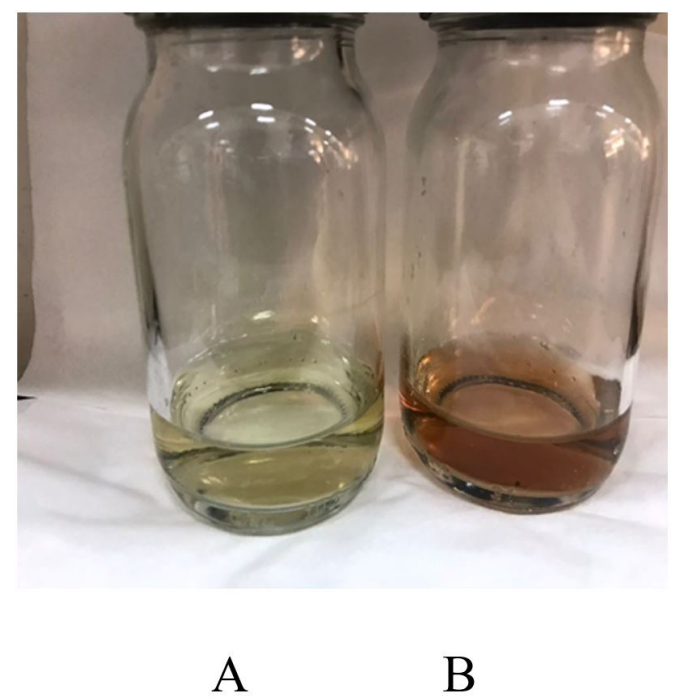

Figure 2. The color changed of plant extract (A) before and (B) after synthesis of silver nanoparticles.
19615, Staphylococcus aureus ATCC 29213, Candida albicane ATCC 14053. All bacterial strains were obtained from microbiology laboratory of King Fahad Hospital in Khobar City - Saudi Arabia.

\subsection{Antibacterial activity}

Sample was dried and grind into powder, $35 \mathrm{~g}$ of finely ground were dissolved in $375 \mathrm{ml}$ of three different solvents (Hexane, ethanol, water) in order to get the best antibacterial effect. The sample of thyme and the three solvents are placed three days in room temperature. Then used rotary evaporator at $60^{\circ} \mathrm{C}$ for 24 hrs for solvents evaporation (hexane and Ethanol) and oils extraction, the extracts were filtered by using disposable membrane bacterial filter to get a sterile extract. Antibacterial activity was determined using agar well diffusion method. Petri -dishes with $20 \mathrm{ml}$ of nutrient agar were equipped, and incubated with $1 \times 10^{6}$ cell $/ \mathrm{ml}, 100 \mu \mathrm{l}$ of a $24 \mathrm{~h}$ broth culture of test bacteria. Wells of $6 \mathrm{~mm}$ diameter each were made and filled with $100 \mu \mathrm{ml}$ of essential oils. The plates were incubated for $24 \mathrm{~h}$ at $37^{\circ} \mathrm{C}$. After incubation, the diameter of inhibition zone was measured in $\mathrm{mm}$ (National Committee for Clinical Laboratory standard).

\section{Results and Discussion}

\subsection{Thymus (Vulgaris) silver nanoparticles}

The reduction of silver ion into silver nanoparticles during exposure to the plant extract could be followed by color change from yellow (Figure 2A) to brown (Figure 2B), Researchers reported that the bark extracts were place yellow in color before addition of $\mathrm{AgNO}_{3}$ and these were changed to brownish color suggested the rapid formation of silver nanoparticles after lumen. The change of color indicates the biosynthesis of silver nanoparticles exhibit brown color in aqueous solution due to the surface Plasmon resonance phenomenon. The appearances of -yellowish -brown color in the reaction vessels suggest the formation of silver nanoparticles (SNPs) (Shankar et al., 2004).

\subsection{Transmission Electron Microscopy (TEM)}

Thymus (Vulgaris) silver nanoparticles TEM images are shown in Figure 3. The average particle size about 8-105nm are investigated. The nanoparticles morphology were

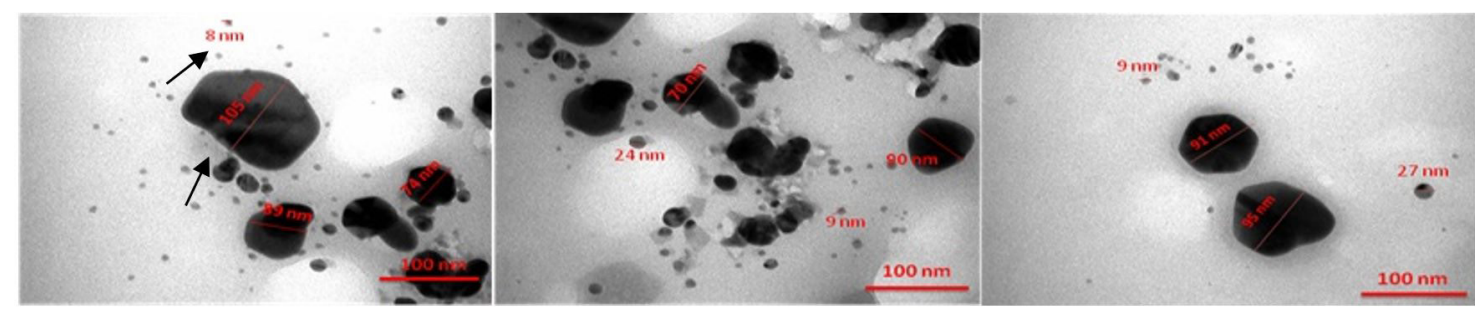

Figure 3. TEM images thymus silver nanoparticles. 
spherical in nature. Our results agree with Abd El-Aziz and Yousef (2018), they reported that silver nanoparticles $\left(\mathrm{AgNP}_{\mathrm{S}}\right)$ are spherical with varying size (in the range from 10-31.7 nm). TEM analysis revealed that the $\mathrm{AgNP}_{\mathrm{S}}$ were primarily spherical in shape. Their size ranges from in between 5-85 nm (Ashraf et al., 2016). The average particle size of AgNPs was about 30-50 nm and spherical shape (Al-Jameel et al., 2018).

\subsection{GC/MS analysis}

GC-MS of TEOE identified 40 chemicals constituent totaling $99.99 \%$, of these pheno 1,2 methyle 5 (1 methylethyle) (CAS) and thymol are the major compounds (48.75 and 32.42, respectively). Also, oil extract contained 1,2 Benzen dicarboxylic acid o, 3 nitro (CAS) (8.12\%), Thymo quinone and Methyl 3 bromo 5 chloro 6 methyl 2,4 bis [2(trimethylsily l)ethoxymethoxy] Benzoate (1.30 and $1.81 \%$ ), respectively (Table 1$)$. These results agree with Dober and Niculita (2012) they reported that GC/MS identified about 16 chemicals from essential oil of Thyme (Vulgaris), they observed 93.97\% totaling. The major compound was Tymol (32.63\%), then cymene, carvacrol, $\gamma$ - terpinen, linalol, $\alpha$ - pinen and $\beta$ - cariofilen were $(25.44 \%),(12,87 \%),(7.17 \%),(4.65 \%),(2.23 \%)$ and (2.07\%), respectively.

Shapiro and Guggenheim (1995) indicated that carvacrol (66.64\%) concentration of the essential oil of Origanumsyriacum has an increased than the essential oil of Thymus vulgaris which is rich in p-cymen and thymol, they observed (30.26\%) and (29.74\%), respectively (European Medicines Agency, 2009).

\subsection{Antioxidant activity}

The TEOE and $\mathrm{TSNP}_{\mathrm{S}}$ reduced DPPH radical formation in dose-dependent manner (Table 2). The TEOE and $\mathrm{TSNP}_{\mathrm{S}}$ at 500 and $1000 \mathrm{ug} / \mathrm{ml}$ exhibited the highest $\mathrm{DPPH}$ - scavenging activity $(87.3,88.5(\mu \mathrm{g} / \mathrm{ml})$ and $(96.1$, $97.2(\mu \mathrm{g} / \mathrm{ml})$, respectively, while $10 \mathrm{ug} / \mathrm{ml}$ exhibited relatively low DPPH - scavenging activity (20.8 and $38.9 \%$ ), respectively. Table 2 also, shows that the TSNP gave the best results at 500 and $1000 \mathrm{ug} / \mathrm{ml}$ compared TEOE. Additionally, these results close to control values that showed in ascorbic acid, this results may be due to the importance of the antioxidant compounds (phenols compounds: Pheno 1,2 methyl 5(1 methylethyl) (CAS), Thymol and Thymoquinone). Thyme have antioxidant capacity due to its contents of flovanoids (Lacroix et al., 1997) and hydroxylated compounds such as terpenoids in their composition (Kadri et al., 2013). The compounds present in thyme leaf extract are Carvacrol, Thymo 1,1-8-Cinote, P-Cymene, Borneol [Lee et al. (2005); Solomakos et al. (2008)], chlorogenic hemihydrate, p-coumaric acid, tannic, syringic, gallic, trans-cinnamic rosmarinic, caffeic and ferulic (Msaada et al., 2016). T. vulgaris also has similar composition, which has phenols group as the most abundant compound also in the oil, they were (71.6\%). In Thymus and their antioxidant activity, Wojdyło et. al., (2007) indicated that a highly significant positive correlation ( $R=0.83$; $\mathrm{p}<0.05$ ) between polyphenols and the activety of
Lamiaceae anti-radical, which indicated that antioxidant compounds are very importance in spices. Msaada. et al., (2016) reported that the collect region was highly influence on the Thyme methanol extract (the activity of anti-radical of methanolic extracts showed activity dependent on the region). The extract of Boukornine shows stronger and highest ( $10 \pm 0.98 \mu \mathrm{g} / \mathrm{mL}$ ) activity than BHT $(16 \pm 1.89 \mu \mathrm{g} / \mathrm{mL})$ and positive control, also Bounatirou et al., (2007) reported the extract lower concentrations ( 750 and $1000 \mathrm{mg} / \mathrm{mL}$ ) has more effectivness as an antioxidant.

\subsection{Antimicrobial activity}

Table 3 shows the antimicrobial activity of TEOE and $\mathrm{TSNP}_{\mathrm{S}}$. The results showed all extracts had antimicrobial properties on bacteria and yeast in Table 3 and were able to prevent the growth of all microorganisms (grampositive, gram - negative and fungi) except Streptococcus pyogenes, it is resistance all extracts, AM and CIP. T+H extract is more effect than all extracts and AM. The results show that the effect of $\mathrm{TSNP}_{\mathrm{S}}$ is more than $\mathrm{AgNo}_{3}$ with Acinetobacter baumanii and St. epidermidis, also, T+E is more effect with Klebsiella peneumonia, Acinetobacter, St. epidermidis, St. aureus and Candida albicane than E extract. Additionally, $\mathrm{T}+\mathrm{W}$ was able to prevent the growth of all microorganisms than $\mathrm{W}$ extract except Acinetobact, st. agalacticae, st. pyogenes and candida albicane, they were resistance both extracts ( $T+W$ and $W$ ). These results may be due to the important source of bioactive compounds with antibacterial capacities against several Gram-positive and Gram-negative bacteria in thymus (Vulgaris). Studies of other researchers have also confirmed our results, three studies of the Thymus oil extracted effect against yeasts and bacterial isolate which found that, the highest percentage of inhibition was $63.4 \%, 61.7 \%, 60.5 \%, 59.7 \%$ and $59.7 \%$ within $30 \%$ concentration for yeasts C. albican, C. rropicalis, C. glabrata, C. kefyr and C. guillermondii, respectively (Habib et al., 2007). Also the highest percent of inhibition was $39 \%, 36.1 \%$ and $27.5 \%$ with $20 \%$ concentration for Staphylococcus aureus, Streptococcus pyogenes and Escherichia coli, respectively. It was shown that inhibition activity of aqueous extracts against Pseudomonas aeruginosa higher compared with other bacteria. The alcoholic extract was more effect on Pseudomonas aeruginosa than another bacteria Staphylococcus aureus and Escherichia coli. Also, Thyme essential oil has antibacterial effects on bacteria isolated from mastitis (Streptococcus agalactiae, Staphylococcus aureus and Escherichia coli)(Mahdi et al., 2013). The clove bud oil presented a MIC of $600 \mathrm{ppm}$ for all the strains of bacterial tested and Thyme essential oil of 400 ppm. However, S. enteritid is and E. coli more sensibility compared to B. cereus and $S$. aureus in the medium containing clove essential oil and thyme (Zahraei-salehi et al., 2005). There were no significant anti-bacterial effects on Staphylococcus aureus with Thyme extract and peppermint extract in concentration of 3.12\%. The essential oils and antimicrobial properties of plant extracts could be used as natural alternative to antibiotics (Abiramasundari et al., 2011). 
Table 1. Main components (\%) detected by GC/MS.

\begin{tabular}{|c|c|c|}
\hline Compound Name & RT & Area\% \\
\hline Á Myrcene & 10.69 & 0.26 \\
\hline 1(7),4,8oMenthatrieNe & 14.23 & 0.62 \\
\hline (1S-(1Alpha,2alpha,4beta))1isopropenyl4methyl1,2cyclohexanediol & 18.74 & 0.09 \\
\hline 1,7,7trimethyl2hydroxybicyclo[2.2.1]heptanes & 19.66 & 0.29 \\
\hline 3Cyclohexen1ol,4methyl1(1 methylethyl)(CAS) & 20.10 & 0.19 \\
\hline Thymoquinone & 22.67 & 1.81 \\
\hline Ncarbobenzyloxycyst Eine & 24.06 & 0.25 \\
\hline Phenol,2methyl5(1 methylethyl)(CAS) & 24.42 & 48.75 \\
\hline Thymol & 24.80 & 32.42 \\
\hline Docosane (CAS) & 27.58 & 0.06 \\
\hline Caryophyllene & 28.31 & 0.46 \\
\hline àHumulene(CAS) & 29.37 & 0.18 \\
\hline NAPHTHALENE,1,2,3,4,4A,5,6,8AOCTAHYDRO7METHYL4METHYLENE1(1METHYLETHYL),(1à,4Aà,8Aà) & 30.06 & 0.07 \\
\hline Octadecane,3ethyl5(2ethylbutyl) & 30.69 & 0.07 \\
\hline BUTYL HYDROXYTOLUENE & 31.13 & 0.52 \\
\hline Phenol,2,5bis(1,1dimethylethyl) & 31.23 & 0.34 \\
\hline Naphthalene,1,2,3,5,6,8ahexahydro4,7dimethyl1(1methylethyl),(1Scis) & 31.49 & 0.09 \\
\hline 2,3dicyano7,7dimethyl5,6benzonorbornadiene & 31.96 & 0.03 \\
\hline Caryophyllene oxide & 33.30 & 0.26 \\
\hline Hexadecane (CAS) & 33.64 & 0.13 \\
\hline Docosane (CAS) & 36.44 & 0.09 \\
\hline Docosane (CAS) & 39.10 & 0.10 \\
\hline 1,2Benzenedicarboxylic acid,bis(2methylpropyl)ester(CAS) & 40.91 & 0.41 \\
\hline Nonacosane (CAS) & 41.64 & 0.04 \\
\hline 2,5,5,8aTetramethyl1,2,3,5,6,7,8,8aoctahydronaphthalen1ol & 41.79 & 0.12 \\
\hline 4Fluorobiphenyld(5) & 42.44 & 0.14 \\
\hline 3,4,7Triphenylpyridazino $\left[4^{\prime}, 3^{\prime}: 4,5\right]$ thieno[3,2b][1,8]naphthyridine & 43.30 & 0.08 \\
\hline Octadecane,3ethyl5(2ethylbutyl) & 44.06 & 0.03 \\
\hline TrimethyltriphenylcyclOtrisiloxane & 48.20 & 0.04 \\
\hline Benzo[h]quinolino[1",2":1',2']imidazo[4',5':4,5]imidazo[1,2a]benzo[h]quinolone & 48.90 & 0.31 \\
\hline 50MethylxanthoneV1 & 49.27 & 0.08 \\
\hline Methyl3bromo5chloro6methyl2,4bis[2(trimethylsilyl)ethoxymethoxy]benzoate & 50.85 & 0.11 \\
\hline 9,19Cyclo9álanost7en3áol,Acetate & 51.71 & 0.11 \\
\hline 3Hydroxy4,4,6a,8a,11,11,14bheptamethyl1,3,4,4a,5,6,6a,7,8,8a,9,10,11,12,12a,14,14a,14boctadecahydro2Hpicen13one & 54.82 & 0.11 \\
\hline Methyl3bromo5chloro6methyl2,4bis[2(trimethylsilyl)ethoxymethoxy]benzoate & 55.27 & 1.30 \\
\hline 1,2Benzenedicarboxylic acid, 3nitro(CAS) & 55.79 & 8.12 \\
\hline (22E)3áAcetoxy7.alpha,hydroperoxystigmasta5,22diene & 57.24 & 0.30 \\
\hline Methyl3',4,4',5,5',6hexamethoxybiphenyl2carboxylate & 64.05 & 0.86 \\
\hline METHYLCOMMATE D & 64.33 & 0.22 \\
\hline $\begin{array}{l}\text { 16(1,3Dimethyl1Hpyrazol4ylmethylene)3hydroxy10,13dimethyl1,2,3,4,7,8,9,10,11,12,13,14,15,16tetradecahydro } \\
\text { cyclopenta[a]phenanthren17one }\end{array}$ & 65.20 & 0.53 \\
\hline
\end{tabular}


Table 2. Free radical scavenging activity (DPPH) of the Thymus (Vulgaris) essential oil and Thymus (Vulgaris) silver nanoparticles.

\begin{tabular}{lccccc}
\hline & \multicolumn{5}{c}{ Radical scavenging activity in \% } \\
\cline { 2 - 6 } & $\mathbf{1 0}(\mu \mathbf{g} / \mathbf{m l})$ & $\mathbf{5 0}(\mu \mathbf{g} / \mathbf{m l})$ & $\mathbf{1 0 0}(\mu \mathbf{g} / \mathbf{m l})$ & $\mathbf{5 0 0}(\mu \mathbf{g} / \mathbf{m l})$ & $\mathbf{1 0 0 0}(\mu \mathbf{g} / \mathbf{m l})$ \\
\hline Thymus (Vulgaris) essential oil (Methanol solvent) & 20.8 & 78.4 & 81.7 & 87.3 & 88.5 \\
Thymus (nanoparticles) & 38.9 & 90.3 & 95.1 & 96.1 & 97.2 \\
Ascorbic acid (positive control) & 48.2 & 93.2 & 96.3 & 97.6 & 97.2 \\
\hline
\end{tabular}

Table 3. Antimicrobial activity of Thymus (Vulgaris)essential oils and Thymus (Vulgaris) silver nanoparticles.

\begin{tabular}{|c|c|c|c|c|c|c|c|c|c|c|c|}
\hline \multirow{2}{*}{ microorganisms } & \multicolumn{11}{|c|}{ Inhibition zone diameter (mm) } \\
\hline & & AM & CIP & $\mathrm{AgNO}_{3}$ & w & $\mathbf{H}$ & $\mathbf{E}$ & TSNPs & $\mathrm{T}+\mathrm{W}$ & $\mathbf{T}+\mathbf{H}$ & $\mathrm{T}+\mathrm{E}$ \\
\hline 1-E.coli & $\begin{array}{c}\text { ATCC } \\
25922\end{array}$ & 26 & $\mathrm{R}$ & 20 & $\mathrm{R}$ & $\mathrm{R}$ & 28 & 18 & 19 & 29 & 19 \\
\hline 2- Kelbsiella oxytoca & $\begin{array}{c}\text { ATCC } \\
700324\end{array}$ & 14 & $\mathrm{R}$ & 20 & $\mathrm{R}$ & $\mathrm{R}$ & 19 & 15 & 11 & 26 & 17 \\
\hline 3- Klebsiella peneumonia & $\begin{array}{c}\text { ATCC } \\
100324\end{array}$ & 10 & 37 & 28 & $\mathrm{R}$ & $\mathrm{R}$ & 15 & 24 & 14 & 24 & 16 \\
\hline 4- Pesudomones aeruginosg & $\begin{array}{c}\text { ATCC } \\
27853\end{array}$ & $\mathrm{R}$ & 35 & 28 & $\mathrm{R}$ & $\mathrm{R}$ & 22 & 15 & 13 & 15 & 16 \\
\hline 5- Acinetobacter baumanii & $\begin{array}{c}\text { ATCC mra } \\
747\end{array}$ & 19 & 20 & 17 & $\mathrm{R}$ & $\mathrm{R}$ & 17 & 19 & $\mathrm{R}$ & 32 & 22 \\
\hline 6-Enterobacter aerogenes & $\begin{array}{c}\text { ATCC } \\
13048\end{array}$ & 17 & 35 & 16 & $\mathrm{R}$ & $\mathrm{R}$ & 23 & 15 & 24 & 21 & 16 \\
\hline 7-Streptococcus dgalacticae & $\begin{array}{l}\text { ATCC } \\
12336\end{array}$ & $\mathrm{R}$ & $\mathrm{R}$ & $\mathrm{R}$ & $\mathrm{R}$ & $\mathrm{R}$ & $\mathrm{R}$ & $\mathrm{R}$ & $\mathrm{R}$ & $\mathrm{R}$ & $\mathrm{R}$ \\
\hline $\begin{array}{l}\text { 8-Staphylococcus } \\
\text { epidermindis }\end{array}$ & $\begin{array}{l}\text { ATCC } \\
12228\end{array}$ & 30 & 36 & 24.3 & $\mathrm{R}$ & 18 & 14 & 28 & 16 & 35 & 29 \\
\hline 9-Streptococcus pyogenes & $\begin{array}{l}\text { ATCC } \\
19615\end{array}$ & $\mathrm{R}$ & $\mathrm{R}$ & $\mathrm{R}$ & $\mathrm{R}$ & $\mathrm{R}$ & $\mathrm{R}$ & $\mathrm{R}$ & $\mathrm{R}$ & $\mathrm{R}$ & $\mathrm{R}$ \\
\hline 10-Staphylococcus aureus & $\begin{array}{c}\text { ATCC } \\
29213\end{array}$ & 22 & 19 & 18 & $\mathrm{R}$ & $\mathrm{R}$ & 15 & 15 & 18 & 33 & 27 \\
\hline 11- Candida albicans & $\begin{array}{c}\text { ATCC } \\
14053\end{array}$ & $\mathrm{R}$ & $\mathrm{R}$ & $\mathrm{R}$ & $\mathrm{R}$ & 22.3 & 26 & $\mathrm{R}$ & $\mathrm{R}$ & 31 & 31 \\
\hline
\end{tabular}

$\mathrm{R}=$ Resistance; $\mathrm{AM}=$ amoxicillin; $\mathrm{CIP}=$ Ciprofloxacin; $\mathrm{AgNo}_{3}=$ Silver nitrate; $\mathrm{W}=$ water; $\mathrm{H}=$ Hexane; $\mathrm{E}=\mathrm{Ethanol} ; \mathrm{TSNPS}=$ Thymus $($ Vulgaris)+ Silver nanoparticles; $\mathrm{T}+\mathrm{W}=$ Thymus + water; $\mathrm{T}+\mathrm{H}=$ Thymus + Hexane; $\mathrm{T}+\mathrm{E}=$ Thymus + Ethan .

\section{Conclusion}

From the present study, it was concluded that the presence of Thymus (Vulgaris)silver nanoparticles was confirmed by the brown color formation. $\mathrm{TSNP}_{\mathrm{S}}$ average size was about $20-40 \mathrm{~nm}$. The antimicrobial efficacy of $\mathrm{TSNP}_{\mathrm{S}}$ is more than $\mathrm{AgNo}_{3}$ with Acinetobacter baumanii and St. epidermidis. Therefore, it was confirmed that Thymus (Vulgaris) essential oil and silver nanoparticles as medicinal plants can be a good source of natural antioxidant and antimicrobial agents.

\section{Acknowledgements}

The authors gratefully acknowledge use of the services and facilities of the Basic and Applied Scientific Research Centre (BASR) at Imam Abdulrahman Bin Faisal University,
Dammam, Saudi Arabia and the assistance of the Field Crop Technology Research Department, Food Technology Research Institute, Agricultural Research Center, Giza, Egypt. Also, the authors would like to thank Dr. sultan Akhtar, from electron microscopy unit in research center and medical consultants of Imam Abdulrahman Bin Faisal University for providing necessary facilities for TEM of nanoparticles.

\section{References}

ABD EL-AZIZ, D.M. and YOUSEF, N.M.H., 2018. Enhancement of antimicrobial effect of some spices extract by using biosynthesized silver nanoparticles. International Food Research Journal, vol. 25, no. 2, pp. 589-596.

ABIRAMASUNDARI, P., PRIYA, V., JEYANTHI, G.P. and GAYATHRI, D.S., 2011. Evaluation of the Antibacterial activity of Cocculus hirsutus. Hygeia. Journal for Drugs and Medicines, vol. 3, no. 2, pp. 26-31. 
AL-JAMEEL, S.S., EL-RAHMAN, S.N.A. and ALDOSSARY, S.K., 2018. Comparative study of antimicrobial and antioxidant activity of the of Boswellia (frankincense)and synthesized silver nanoparticles. Journal of Food Agriculture and Environment, vol. 16, no. 1, pp. 20-25.

ASHRAF, J.M., ANSARI, M.A., KHAN, H.M., ALZOHAIRY, M.A. and CHOI, I., 2016. Green synthesis of silver nanoparticles and characterization of their inhibitory effects on AGEs formation using biophysical techniques. Scientific Reports, vol. 6, no. 1, pp. 20414. http://dx.doi.org/10.1038/srep20414. PMid:26829907.

BOUNATIROU, S., SMITI, S., MIGUEL, M.G., FALEIRO, L., REJEB, M.N., NEFFATI, M., COSTA, M.M., FIGUEIREDO, A., BARROSO, J.G. and PEDRO, L.G., 2007. Chemical composition antioxidant and antibacterial activities of the essential oils isolated from Tunisian Thymus capitates Hoff et Link. Food Chemistry, vol. 105, no. 1, pp. 146-155. http://dx.doi.org/10.1016/j.foodchem.2007.03.059.

DOBER, A.A. and NICULITA, P., 2012. Antibacterial profile of essential oils against pathogen bacteria. Bulletin UASVM Agriculture, vol. 96, no. 2, pp. 255-261.

EUROPEAN MEDICINES AGENCY, 2009. Assessment report on Thymus vulgaris L., Thymus zygis Loefl. ex. L., aetheroleum, EMA/ HMPC/131903/2009. London: European Medicines Agency.

HABIB, K.A., AL-JUMAILY, E.F. and ABDULMAJEED, S.M., 2007. The effect of oil extracted from thyme thymus vulgaris in candida. Species and Baderia isolated from children infected with oral thrush. Iraqi Journal of Biotechnology, vol. 6, no. 2, pp. 77-87.

JAVANMARDI, J., STUSHNOFF, C., LOCKE, E. and VÝVANCO, J.M., 2003. Antioxidant activity and total phenolic content of Iranian Ocimum accessions. Food Chemistry, vol. 83, no. 4, pp. 547-550. http://dx.doi.org/10.1016/S0308-8146(03)00151-1.

KADRI, A., ZARAI, Z., CHOBBA, I.B., GHARSALLAH, N., DAMAK, M. and BÉKIR, A., 2013. Chemical composition and in vitro antioxidant activities of Thymelaea hirsuta L: essential oil from Tunisia. African Journal of Biotechnology, vol. 10, pp. 2930-2935.

KATSIOTIS, A., NIKOLOUDAKIS, N., LINOS, A., DROSSOU, A. and CONSTANTINIDIS, T., 2009. Phylogenetic relationships in Origanum spp. based on rDNA sequences and intra-genetic variation of Greek O.vulgare subsp. hirtum revealed by RAPD. Scientia Horticulturae, vol. 121, no. 1, pp. 103-108. http://dx.doi. $\operatorname{org} / 10.1016 /$ j.scienta.2009.01.015.

KAUR, C. and KAPOOR, H.C., 2001. Antioxidants in fruits and vegetables-the millennium's health. International Journal of Food Science E Technology, vol. 36, no. 7, pp. 703-725. http:// dx.doi.org/10.1046/j.1365-2621.2001.00513.X.

KRUTYAKOV, Y.A., KUDRYNSKIY, A., OLENIN, A.Y. and LISICHKIN, G.V., 2008. Extracellur biosynthesis and antimicrobial activity of silver nanoparticles. Russian Chemical Reviews, vol. 77, pp. 233. http://dx.doi.org/10.1070/RC2008v077n03ABEH003751.

KUMAR, V. and YADAV, S.K., 2009. Plant-mediated synthesis of silver and gold nanoparticles and their applications. Journal of Chemical Technology and Biotechnology, vol. 84, no. 2, pp. 151-157. http://dx.doi.org/10.1002/jctb.2023.

LACROIX, M., SMORAGIEWICZ, W., PAZDERNIK, L., KONÉ, M.I. and KRZYSTYNIAK, K., 1997. Prevention of lipid radiolysis by natural antioxidants from rosemary (Rosmarinus officinalis $\mathrm{L}$ ) and thyme (Thymus vulgaris L). Food Research International, vol. 30, no. 6 , pp. 457-462. http://dx.doi.org/10.1016/S0963-9969(98)00002-7.

LEE, S., UMANO, K., SHIBAMOTO, T. and LEE, K., 2005. Identification of volatile components in basil (OcimumbasilicumL.) and thyme leaves (Thymus vulgaris L.) and their antioxidant properties. Food Chemistry, vol. 91, no. 1, pp. 131-137. http://dx.doi.org/10.1016/j. foodchem.2004.05.056.
LOSSO, J.N., SHAHIDI, F. and BAGCHI, D., 2007. Anti-angiogenic functional and medicinal foods. Boca Raton: Taylor \& Francis. http://dx.doi.org/10.1201/9781420015584.

MAHDI, K.M., MOHAMMED, Y., MOHAMMED, R. and MANSOUR, G., 2013. Study on antibacterial effect of thyme and peppermint aqueous extraction Staphylococcus aureus and Escherichia coli strains causing mastitis in camels. International Journal of Traditional and Herbal Medicine, vol. 1, no. 4, pp. 112-115.

MATHE, C., CULIOLI, G., ARCHIER, P. and VIEILLESCAZES, C., 2004. Characterization of archeological frankincense by gas chromatography-mass spectrometry. Journal of Chromatography. A, vol. 1023, no. 2, pp. 277-285. http://dx.doi.org/10.1016/j. chroma.2003.10.016. PMid:14753694.

MIURA, K. and NAKATANI, N., 1989. Antioxidant activity of flavonoids from thyme (Thymus vulgaris L). Agricultural and Biological Chemistry, vol. 53, pp. 3043-3045.

MORENO, M.I., ISLA, M.I., SAMPIETRO, A.R. and VATTUONE, M.A., 2000. Comparison of the free radical-scavenging activity of propolis from several regions of Argentina. Journal of Ethnopharmacology, vol. 71, no. 1-2, pp. 109-114. http://dx.doi. org/10.1016/S0378-8741(99)00189-0. PMid:10904153.

MSAADA, K., TAMMAR, S., SALEM, N., BACHROUCH, O., SRITI, J., HAMMAMI, M., SELMI, S., AZAIEZ, S., HADJ-BRAHIM, A., AL SANE, K., LIMAM, F. and MARZOUK, B., 2016. Chemical composition and antioxidant activities of tunisian Thymus capitatus L methanolic extract. International Journal of Food Properties, vol. 19, no. 6, pp. 1381-1390. http://dx.doi.org/10.1 080/10942912.2015.1082138.

SAVITHRAMMA, N., LINGA, R.M., RUKMINI, K. and SUVARNALATHA, D.P., 2011. Antimicrobial activity of silver nanoparticles synthesized by using medicinal plants. International Journal of Chemtech Research, vol. 3, no. 3, pp. 1394-1402.

SCALBERT, A., MANACH, C., MORAND, C., REMESY, C. and JIMÉNEZ, L., 2005. Dietary of polyphenols and the prevention of diseases. Critical Reviews in Food Science and Nutrition, vol. 45, no. 4, pp. 287-306. http://dx.doi.org/10.1080/1040869059096. PMid:16047496.

SEBRANEK, J. and BACUS, J., 2007. Natural and organic cured meat products: regulatory, manufacturing, marketing, quality and safety issues. American Meat Science Association, no. 1, pp. 1-15.

SHANKAR, S.S., RAI, A., AHMAD, A. and SASTRY, M.J., 2004. Rapid synthesis of $\mathrm{Au}, \mathrm{Ag}$, and bimetallic Au core-Ag shell nanoparticles using Neem (Azadirachta indica) leaf broth. Journal of Colloid and Interface Science, vol. 275, pp. 496-502. http://dx.doi.org/10.1016/j.jcis.2004.03.003. PMid:15178278.

SHAPIRO, S. and GUGGENHEIM, B., 1995. The action of thymol on oral bacteria. Oral Microbiology and Immunology, vol. 10, no. 4, pp. 241-246. http://dx.doi.org/10.1111/j.1399-302X.1995. tb00149.x. PMid:8602337.

SLMAN, A.A., 2012. Antibacterial activity of Zno nanoparticle on some gram-positive and gram- negative bacteria. Iraqi Journal of Physics, vol. 18, pp. 5-10.

SOKMEN, A., GULLUCE, M., AKPULAT, H.A., DAFERERA, D., TEPE, B., POLISSIOU, M., SOKMEN, M. and SAHIN, F., 2004. The in vitro antimicrobial and antioxidant activities of the essential oils and methanol extracts of endemic Thymus spathulifolius. Food Control, vol. 15, no. 8, pp. 627-634. http://dx.doi.org/10.1016/j. foodcont.2003.10.005.

SOLOMAKOS, N., GOVARIS, A., KOIDIS, P. and BOTSOGLOU, N., 2008. The antimicrobial effect of thyme essential oil, nisin, and their combination against Listeria monocytogenes in minced beef during refrigerated storage. Food Microbiology, vol. 25, 
no. 1, pp. 120-127. http://dx.doi.org/10.1016/j.fm.2007.07.002. PMid:17993385.

WOJDYŁO, A., OSZMIANSKI, J. and CZEMERYS, R., 2007. Antioxidant activity and phenolic compounds in 32 selected herbs. Food Chemistry, vol. 105, no. 3, pp. 940-949. http://dx.doi. org/10.1016/j.foodchem.2007.04.038.
ZAHRAEI-SALEHI, T., VOJGANI, M., BAYAT, M., TORSHIZI, H. and AKHONDZADE, A., 2005. Determination of minimum inhibitory concentration of extract of Zataria Multiflora against the clinical isolates of Streptococcus agalactiae, Escherichia coli and Staphylococcus aureus. Iranian Journal of Veterinary Medicine University of Tehran, vol. 60, pp. 107-110. 